\title{
THREE NEW CRETACEOUS ACULEATE WASPS (HYMENOPTERA)
}

\author{
By Howard E. Evans \\ Museum of Comparative Zoology
}

Aculeate Hymenoptera have been known from the Mesozoic only from the Upper Cretaceous wasp Cretavus sibiricus (Sharov, 1957) and the ant Sphecomyrma freyi, known from two workers from the lower part of the Upper Cretaceous (Wilson, Carpenter, and Brown, 1967). Wasps evidently quite similar to living forms are, however, known from the Green River shales, of Eocene age (Cockerell, I922), as are several ants, and a diversity of wasps, ants, and bees occur in Baltic Amber. Thus it has seemed probable that the Aculeata underwent a radiation in the Cretaceous, although the scarcity of fossil insects from this period has made it difficult to document this radiation.

Quite recently three fossil wasps from Cretaceous deposits have come to my attention. These do indeed indicate that the Aculeata became quite diversified before the end of the Mesozoic. One of these wasps, which I have placed in the new genus Archisphex, has a generalized aculeate venation but is very probably a sphecid. Only one wing is preserved, but this is in good condition and is noteworthy as the first evidence of an aculeate to be found in Lower Cretaceous deposits. A second wasp, described in the new genus Lisponema, is an undoubted sphecid, having a specialized wing venation strikingly similar to that of the modern genus Spilomena (Pemphredoninae). It is known from a headless but otherwise well preserved specimen from Cedar Lake Amber (Manitoba, Canada). Another wasp in these same deposits is a bethyloid obviously related to the cuckoo wasps, which I have placed in the new genus Procleptes; it is also quite well preserved although lacking most of the wings.

Thus there is now evidence that three diverse stocks of aculeates (sphecids, bethyloids, and ants) were present in the Cretaceous. Cretavus is usually assumed to be a scolioid (although there are certain unusual features of the wing), and eumenid wasps are known from the Eocene (Evans, 1966, p. 394). Thus we may say that representatives of three superfamilies were certainly present in the Cretaceous, two others almost certainly. These include the ancestral stocks of all the social forms, since the vespids were surely derived from eumenid stock, the bees from a primitive sphecid perhaps not 
greatly unlike Archisphex. Further discussion of phylogeny is deferred until after these specimens have been described.

My own role in these discoveries has simply been to place them in the scientific record. The Lower Cretaceous Archisphex was collected by R. A. Crowson of the University of Glasgow and very kindly presented to Harvard University. The two specimens from Cedar Lake, Manitoba, were collected by F. M. Carpenter, who also took a great deal of care in preparing the small pieces of amber so that the specimens could be studied in detail. These two specimens were first recognized as aculeates by Edgar Riek, of C.S.I.R.O. in Canberra, Australia, while he was sorting unworked material during a recent visit to Harvard. Various persons have advised me on the placement of these specimens, but $\mathrm{I}$ am particularly indebted to R. M. Bohart and A. S. Menke, who are currently preparing a revision of the genera of living Sphecidae.

\section{Archisphex, new genus}

Based on a single nearly complete fore wing (Fig. I), the more critical features of which are as follows: costal cell present; stigma elongate, lower margin nearly straight, outer margin oblique, straight; marginal cell (cell $\mathrm{R}_{\mathrm{I}}$ ) with its apex on the wing margin, not far from wing tip, and slightly appendiculate (i.e., R I extending beyond apex of cell); three fully formed submarginal cells and three fully formed discoidal cells present (i.e., veins Rs, $2 \mathrm{r}-\mathrm{m}, 3 \mathrm{r}-\mathrm{m}, \mathrm{I} \mathrm{m}-\mathrm{cu}$, and $2 \mathrm{~m}$-cu all complete), second recurrent vein $(2 \mathrm{~m}-\mathrm{cu})$ curved basad so as to reach the second submarginal cell near its outer corner, first recurrent vein ( $\mathrm{I} \mathrm{m}$-cu) almost interstitial with first intercubital (Rs); major wing veins ( $M$ and Cula) reaching outer wing margin; basal vein ( $M+R s)$ only slightly oblique, its upper terminus at some distance from stigma; transverse median vein (cu-a) oblique, reaching media $(\mathrm{M}+\mathrm{Cu}$ ) slightly basad of origin of basal vein; veins and stigma brown in color; wing membrane with close-set microtrichiae.

Type species: Archisphex crowsoni, new species

The name Archisphex is simply Greek for "ancient wasp" and should not influence future students toward keeping this genus in the Sphecidae if new evidence suggests that it belongs elsewhere. For the present, I do regard this wasp as probably a sphecid, largely by a process of elimination from other families plus a close approximation of the wing to certain living sphecids. These two considerations also provide a measure of certainty that Archisphex is an 


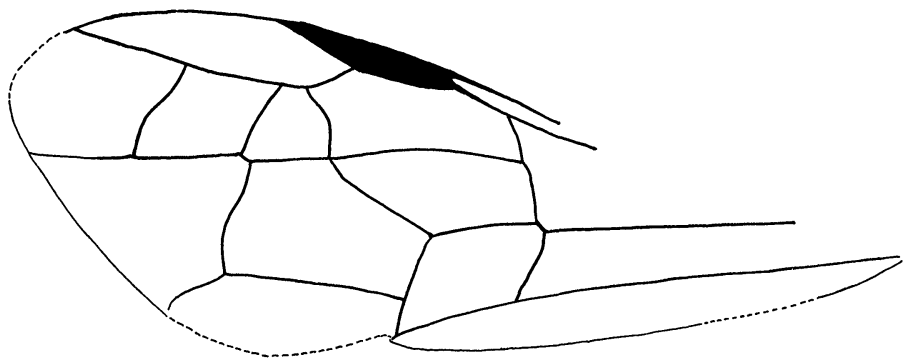

Fig. 1. Archisphex crowsoni n. sp., type specimen (traced from a photograph).

aculeate; a venation of this type is not approximated by any Symphyta or Terebrantia, but is very close to what might be regarded as the "basic pattern" of venation for the Aculeata. The one unusual feature, the curvature of the second recurrent vein to join the second submarginal cell, provides a major reason for placing it in the Sphecidae. However, unless the body is eventually found, it will never be possible to state unequivocally that it is a sphecid and not a very generalized scolioid, trigonalid, or representative of some extinct family of wasps.

Evidence for eliminating Archisphex from other living families of wasps is as follows: The full complement of veins and cells makes it improbable that it belongs in the Bethyloidea or in such families as the Formicidae, Plumariidae, or Rhopalosomatidae; the nearly erect, straight basal vein further eliminates these three families and also (and especially) the Vespoidea. All Trigonalidae known to me have a more oblique basal vein as well as modifications of the submarginal cells, also a second recurrent vein which terminates in the third submarginal. I am not familiar with any Pompilidae or Apoidea in which the second recurrent curves basad to reach the second submarginal cell. Some Scolioidea have a venation very similar to this specimen, and in the males of Anthoboscinae and Thynninae the second recurrent vein does indeed often reach the second submarginal cell. However, in both these groups, as in most Scolioidea, there is an additional vein or crease beneath the stigma (regarded as I $\mathrm{r}$ ), marking off a small apical part of the first submarginal cell. There is no evidence whatever of this vein in Archisphex, leaving the family Sphecidae as the most likely possibility.

Within the Sphecidae there are fairly numerous genera having this basic venation. A. S. Menke has suggested that this fossil may 
represent a member of the Pemphredoninae, tribe Psenini, perhaps close to Psenulus. It is approximately the same size as living members of this genus and the venation is very similar indeed. As compared to Archisphex, Psenulus fuscipennis has a somewhat shorter and wider stigma, a slightly different slope to the basal and transverse median veins (but the two meet media in the same manner), a first recurrent vein which attains the inner corner of the second submarginal cell, and major veins ( $M$ and Cula) which reach the wing margin only as thin streaks. It is tempting to regard Archisphex as a pemphredonine, as the species to be described below, from the Upper Cretaceous, quite definitely belongs in that subfamily. However, generalized members of several other subfamilies have a venation sufficiently similar to this so that it is impossible to say that if Archisphex is a sphecid it is surely a pemphredonine. A basically similar venation occurs, for example, in the nysonnine genus Clitemnestra and in the sphecine genus Hemichalybion (although the latter is a much larger wasp). Little more can be said about the possible position of Archisphex; we can only hope that other fossils will be discovered which will eventually tie it in with greater assurance to some group of wasps.

Archisphex crowsoni, new species

Length of fore wing $5 \mathrm{~mm}$; features as shown in Fig. I. I would

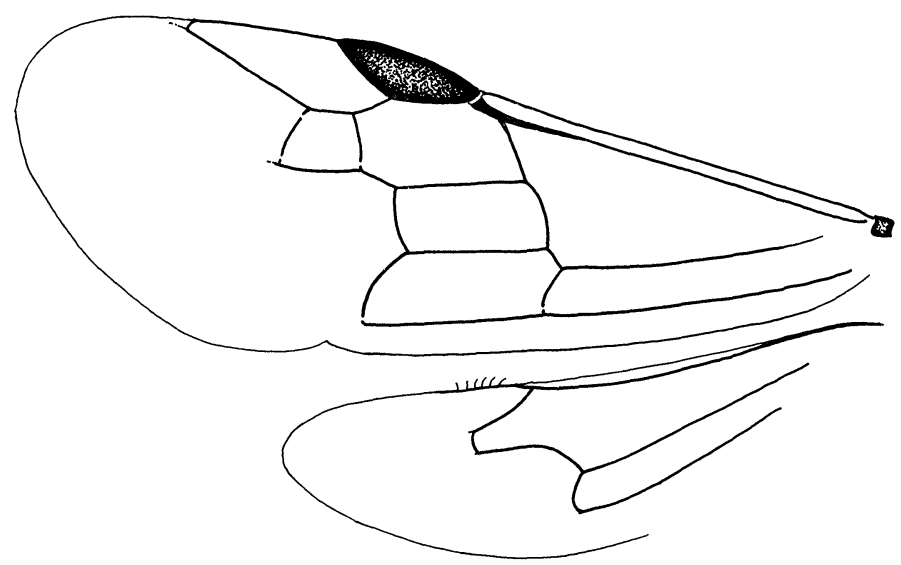

Fig. 2. Lisponema singularis $\mathrm{n}$. sp., wings of type specimen. In the specimen, the fore wings are somewhat curled, the hind wings beneath the fore wings; they are shown here as if drawn apart and flattened. 
assume that this wasp had a wing span of about $12 \mathrm{~mm}$ and a body length of $7-9 \mathrm{~mm}$. No color pattern is evident on the wing.

Specimen from Wadhurst Clay, Quarry Hill Pit, Tunbridge, England (Lower Cretaceous). ${ }^{1}$ Collected by R. A. Crowson in 1939; MCZ no. 6312.

\section{Lisponema, new genus}

Based on a single specimen in amber in nearly perfect condition except lacking nearly all of the head (Figs. 2, 3). The more striking features are as follows: body and legs slender, the latter devoid of spines; tibial spur formula I-I-2; claws weakly dentate; mesoscutum large, parapsidal furrows distinct, notauli vaguely indicated; abdomen slender, sessile; fore wings with a very large stigma; marginal cell (cell $\mathrm{R}_{\mathrm{I}}$ ) measured along wing margin about as long as stigma, its apex curved away from wing margin and weakly appendiculate; two submarginal cells and two discoidal cells present (veins $3 \mathrm{r}-\mathrm{m}$ and $2 \mathrm{~m}$-cu wholly absent), and in general veins and cells far removed from outer wing margin; hind wing with six rather large hamuli visible, veins $R s$ and $M$ not extending beyond $r-m$, submedian cell elongate, its outer end (cu-a) rounded up to meet media at the origin of cubitus (i.e., where $M$ passes up to meet $r-m$ ).

Type species: Lisponema singularis, new species

The name Lisponema is an anagram of Spilomena, the living genus which it resembles most closely; however, it might equally well be taken to mean "smooth thread" (Greek lispos + nema), with reference to the very slender, smooth legs. This genus resembles Spilomena so closely that it can be uniquivocally assigned to the family Sphecidae, subfamily Pemphredoninae, and to that section of the subfamily that includes Spilomena, Microstigmus, Ammoplanus, and certain other genera. While the Pemphredoninae rank as one of the more generalized subfamilies of Sphecidae, these genera are considered to represent one of its more specialized elements. The specializations extend to larval characters and, in Microstigmus, to nest type and probable sociality (Matthews, 1968). The species of Spilomena are solitary wasps that nest in cavities in wood and prey upon thrips. The very close resemblance of Lisponema to members of this genus suggests that it, too, nested in some type of pre-existing cavities; the slender, smooth legs, in particular, indicate that it did not dig in the soil.

\footnotetext{
${ }^{1}$ These relatively poorly known deposits are described by White (1928). The insect fragments from these beds have evidently not been monographed.
} 


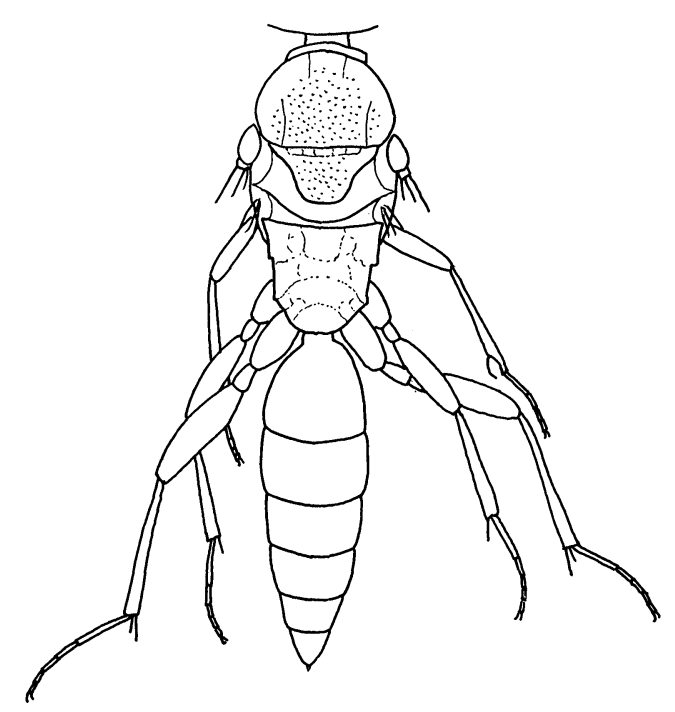

Fig. 3. Lisponema singularis n. sp., dorsal view of type specimen, wings omitted.

As compared to Spilomena barberi, Lisponema singularis has a slightly longer stigma, a marginal cell that curves away from the wing margin, first recurrent vein ( $\mathrm{I} \mathrm{m}$-cu) not at all interstitial with first intercubital (Rs), $\mathrm{M}$ and $\mathrm{Cul}$ separating fairly close to transverse median vein (cu-a), and, in the hind wing, a submedian cell which is longer and more rounded apically. These differences seem to me great enough to justify generic status for Lisponema. Some Pemphredoninae are known in which the marginal cell curves away from the wing margin (e.g. Protostigmus), although these differ in a number of other respects.

\section{Lisponema singularis, new species}

Length of body (without most of head, which is missing) 2.5 $\mathrm{mm}$; length of forewing $1.7 \mathrm{~mm}$. Body fuscous, with no evident maculations; wings hyaline, with brown veins and stigma. Features of body as shown in Fig. 3; thoracic dorsum shining and with small, close punctures; scutellum with a transverse basal groove; propodeum with reticulate sculpturing, the details of which are obscure, laterally with two small dentiform projections on each side; legs smooth and slender, as figured, the hind tibiae with some thin setae but no spines; wings as figured. Abdomen with six clearly visible segments 
and a small terminal projection which probably represents the subgenital plate. (I believe this specimen is a male, even though only six abdominal segments can be detected.)

Specimen in a small block of amber from Cedar Lake, Manitoba (Upper Cretaceous). ${ }^{2}$ Collected by F. M. Carpenter, MCZ no. 6875 .

\section{Procleptes, new genus}

Based on a single specimen in amber, in good condition although with some distortion and compression of the head and thorax, and with the wings absent beyond the basal fifth (Figs. 4, 5). The more striking features are as follows: mandibles rather large, with four apical teeth (but the left mandible with only three evident teeth, the basal one rather broad); palpi apparently short (but may be broken off or distorted) ; antennae arising far below eyes, prominently geniculate, with a long, slender scape and a somewhat longer flagellum of about I 2 segments (cannot be counted precisely; both flagella lie longitudinally beneath the head and appear to be broadened and flattened on the apical two-thirds, but this may be the result of distortion); front with a strong median groove; eyes large, not hairy, ocelli well developed. Pronotum elongate, its posterior margin arcuately emarginate; mesoscutum and scutellum narrow and elongate, separated by a groove (but much compressed and distorted; parapsidal furrows and notauli not visible); propodeum with a large, acute process on each side; wings with several veins as figured; legs elongate, covered with short hairs but without spines except for a few short ones on the tarsi; tibial spur formula I-2-2; front coxae with apical spine-like processes; claws rather large, apparently simple; basal half of abdomen broad, depressed but not evidently concave ventrally, apparently consisting of four segments as figured; apical half of abdomen in the form of a long tube, consisting of three segments, the tip of the sting protruding from the end of the apical segment.

Type species: Procleptes carpenteri, new species

The name Procleptes was chosen to suggest that this wasp may be a member of the stock which gave rise to the modern genus Cleptes

\footnotetext{
${ }^{2}$ For a discussion of this locality and descriptions of other insects, see Carpenter et al (1934). Richards (1966) presents evidence that this amber is at least 72-73 million years old and probably dates from the early Upper Cretaceous, at a time when the climate of this part of Canada was mainly tropical. McAlpine and Martin (1969) give a detailed account of the occurrence of the amber and its probable origin.
} 
(variously placed in the bethyloid family Cleptidae or in the subfamily Cleptinae of the Chrysididae). The resemblance in abdominal structure is especially close (see, e.g., the figure of Cleptes consimilis in Grandi, 1961, Fig. 2, no. 6). The major differences from Cleptes are in the mandibles, which are rather broad and 3 or 4 -toothed apically, as in many Bethylidae (from which the cleptids may well have evolved), in the unusually long and slender scape, and the more prolonged head anterior to the eyes (although some of this may be the result of distortion). The elongate head and somewhat bulging eyes might suggest that this specimen belongs in the subfamily Amiseginae (variously placed in the Cleptidae or Chrysididae); however, the front has a median groove and no specialized sculpturing on the lower part, the mandibles are much broader than in any known Amiseginae, and the abdomen is relatively elongate. The abdomen is not ventrally concave nor otherwise as specialized as in

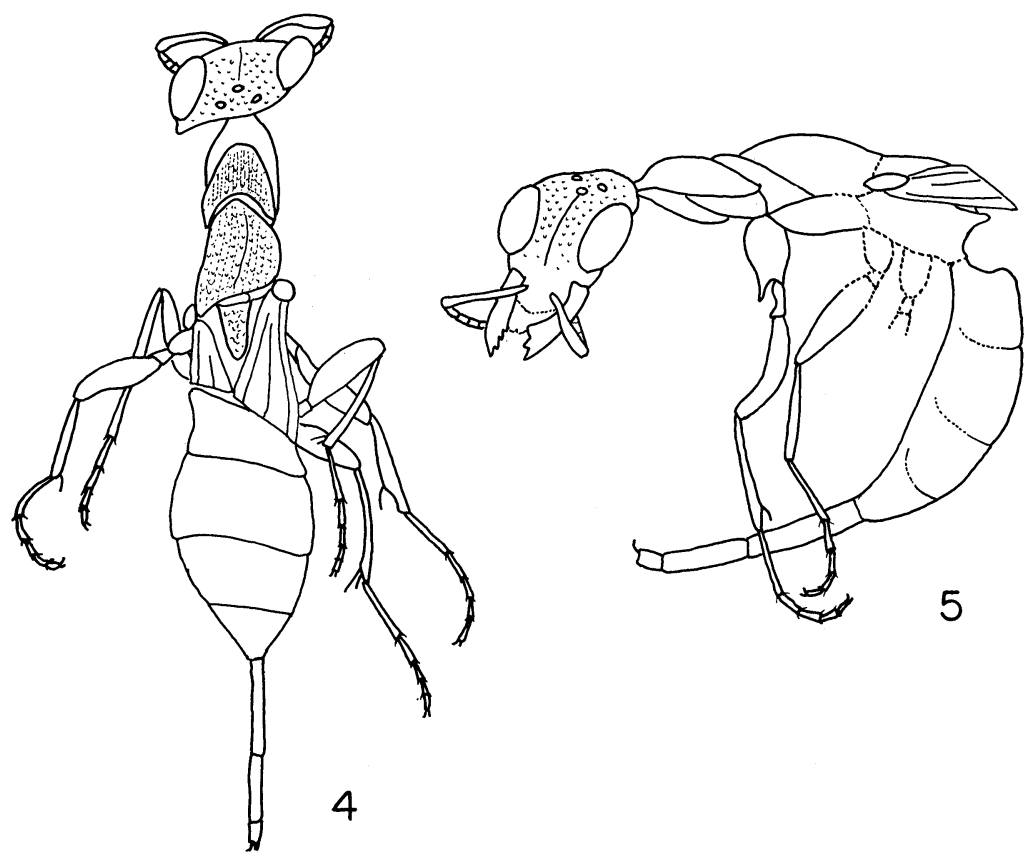

Fig. 4. Procleptes carpenteri n. sp., dorsal view of type specimen. In fact the abdomen is twisted ventrally and forward, as in Fig. 5; in this figure it is shown as if it extended straight backward. Fig. 5. Same specimen, lateral view. 
the true cuckoo wasps (Chrysidinae). It is unlikely that Procleptes was a "cuckoo" in behavior, not only because of its greater resemblance to Cleptinae and Amiseginae but because aculeate hosts must have been relatively scarce in the Cretaceous. Species of Cleptes have been reared from the larvae of sawflies, which may have been plentiful in the Cretaceous, since their fossil record extends back to the Triassic. Amiseginae are parasites of the eggs of walking sticks. I would assume that Procleptes was a parasitoid, and I suggest sawflies as probable hosts, although orthopteroids or indeed many other groups of insects cannot be ruled out as possibilities.

\section{Procleptes carpenteri, new species}

Length of body about $3.2 \mathrm{~mm}$; wings apparently fully developed (although broken off near the base in this specimen). Head and thorax with a distinct blue-green cast, the integument apparently moderately thick and rather strongly punctate, the pronotum longitudinally striatopunctate; legs and abdomen black, non-metallic; body and legs covered with short, whitish hair; other details as figured.

Specimen in a small block of amber from Cedar Lake, Manitoba (Upper Cretaceous), collected by F. M. Carpenter. MCZ no. I 234 .

\section{Discussion}

It comes as a considerable surprise to find such specialized wasps in the Cretaceous. The remarkable tubular development of the apical half of the abdomen of Procleptes is quite like that of modern species, and the unusual and much reduced wing venation of Lisponema is very comparable to that of some of the more specialized living Pemphredoninae. Discovery of quite a typical wing of a wasp from the lowest part of the Cretaceous, however, makes it seem less surprising to find specialized forms in the upper part of that period. The Cretaceous was, after all, a very long period, comparable in length to the entire Tertiary.

I believe that the small size of all three of these wasps is an accident of preservation rather than an indication that all the original Aculeata were small. Dr. R. A. Crowson tells me that the Wadhurst Clays in which Archisphex was found contain mostly small insects and fragments of larger ones; and a small piece of the wing of a large wasp might not be recognizable as such. The bits of amber from Cedar Lake, Manitoba, are all quite small and only very small insects have been preserved in them. The Cretaceous ant 
Sphecomyrma, from New Jersey amber, is described as "mediumsized", while Cretavus is a large wasp, with a wing length of ro $\mathrm{mm}$ (thus with a wing-span of about $23 \mathrm{~mm}$ and a probable body length of I3-I $8 \mathrm{~mm}$ ). There may have been a fairly diverse fauna of Aculeata of various sizes in the Cretaceous, but it happens that the deposits considered here are chiefly favorable for preserving small species, which often happen to have reductions in wing venation and other specializations.

The diversity of Aculeata in the Cretaceous (three superfamilies certainly and two others probably, as pointed out in the introduction) suggests an origin of this group in the Jurassic. Dr. Crowson tells me that the rocks in which Archisphex was found contain a number of insects belonging to Jurassic proups. The Sphecidae undoubtedly diversified rapidly in the Cretaceous, as evidenced by Lisponema and by quite modern-looking Nyssoninae in the Eocene. Lisponema was surely not a ground-nester, and Baltic Amber is rich in Sphecidae which probably nested in hollow twigs and other cavities above ground (including Passaloecus and other genera related to Lisponema). If the Sphecidae arose from a scolioid ancestor one would have expected them to have been originally associated with the soil. In fact they may have been so; twig-nesters tend to occur more abundantly in forested areas and may thus become preserved in amber much more readily. The Pompilidae are sometimes regarded as a somewhat more "primitive" group on the sphecoid stem, but it is noteworthy that none are known from prior to the Oligocene (Baltic Amber) and that the fossils from that epoch belong mainly to archaic genera such as Epipompilus.

The radiation of the Sphecidae in the Cretaceous makes it seem very likely that the bees had their origin in this period and that they were therefore on hand to participate in the early diversification of the flowering plants. The presence of Procleptes in the Upper Cretaceous also suggests that a prototype for the cuckoo wasps was available to take advantage of the proliferation of the bees and wasps during the Tertiary.

Carpenter, F. M., et al.

\section{REFERENCES}

1934. Insects and Arachnids from Canadian Amber. Univ. Toronto Studies, Geol. Series, no. 40, pp. 7-62.

Cockerell, T. D. A.

1922. An ancient wasp. Nature, 110: 313.

Evans, H. E.

1966. The Comparative Ethology and Evolution of the Sand Wasps. Harvard Univ. Press, Cambridge, Mass., $526 \mathrm{pp}$. 
GRANDI, G.

1961. Studi di un entomologo sugli Imenotteri superiori. Boll. Ist. Ent. Univ. Bologna, 25 : 1-659.

Matthews, R. W.

1968. Nesting biology of the social wasp Microstigmus comes (Hymenoptera: Sphecidae, Pemphredoninae). Psyche, 75: 23-45.

McAlpine, J. F. and J. E. H. Martin

1969. Canadian amber - a paleontological treasure chest. Can. Ent. 101: 819-838.

RICHARDS, W. R.

1966. Systematics of fossil aphids from Canadian amber (Homoptera: Aphididae). Canad. Ent., 98: 746-760.

Sharov, A. G.

1957. First discovery of a Cretaceous stinging hymenopteron (Aculeata). Dokl. Akad. Nauk., 112: 943-944 (In Russian).

White, H. J. OSBORNe

1928. The geology of the country near Hastings and Dungeness. Mem. Geol. Survey England, Expl. Sheets 320 and 321, pp. 6, 25-27, 61-69.

Wilson, E. O., F. M. Carpenter, and W. L. Brown, Jr.

1967. The first Mesozoic ants, with the description of a new subfamily. Psyche, 7.4: 1-19. 

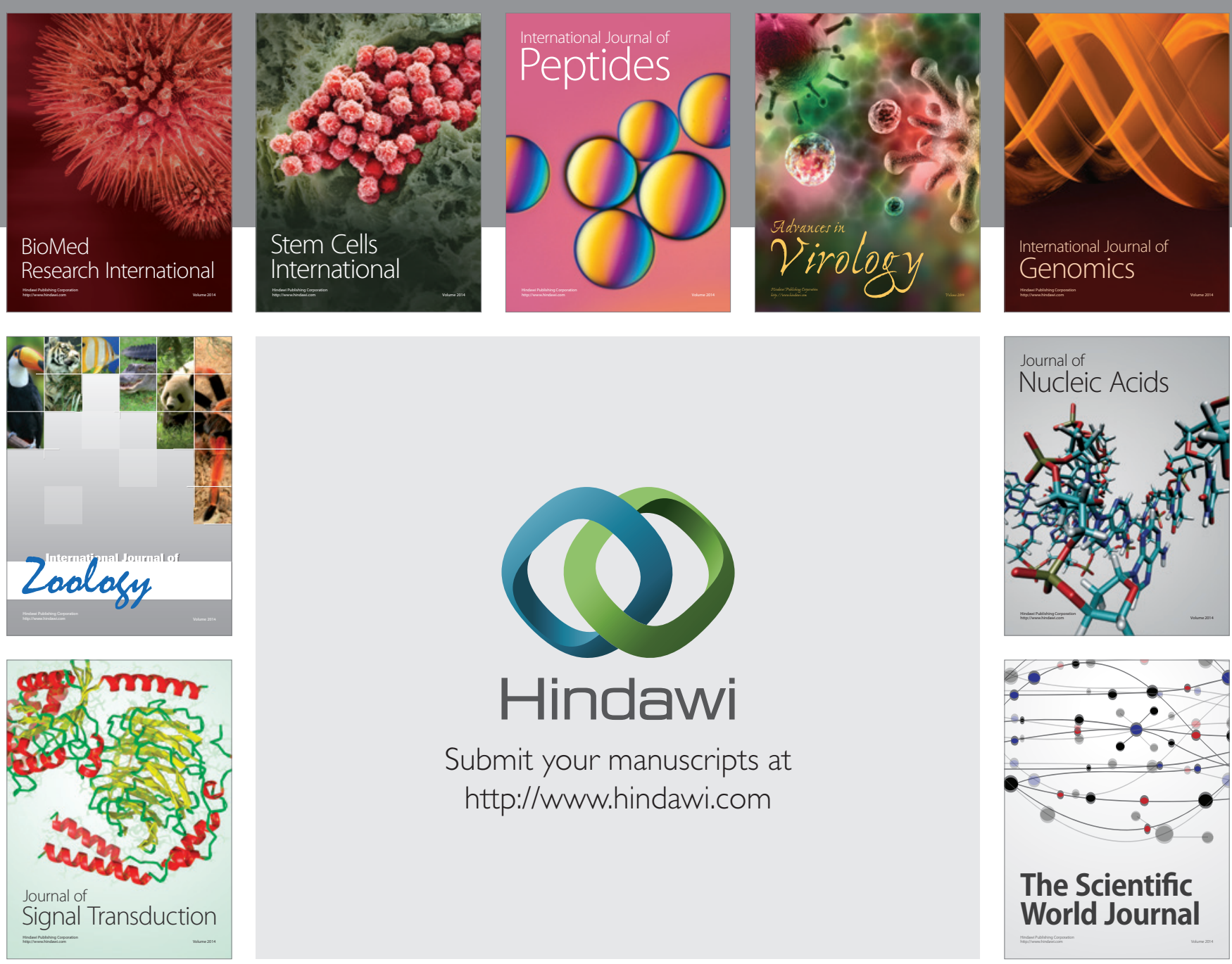

Submit your manuscripts at

http://www.hindawi.com
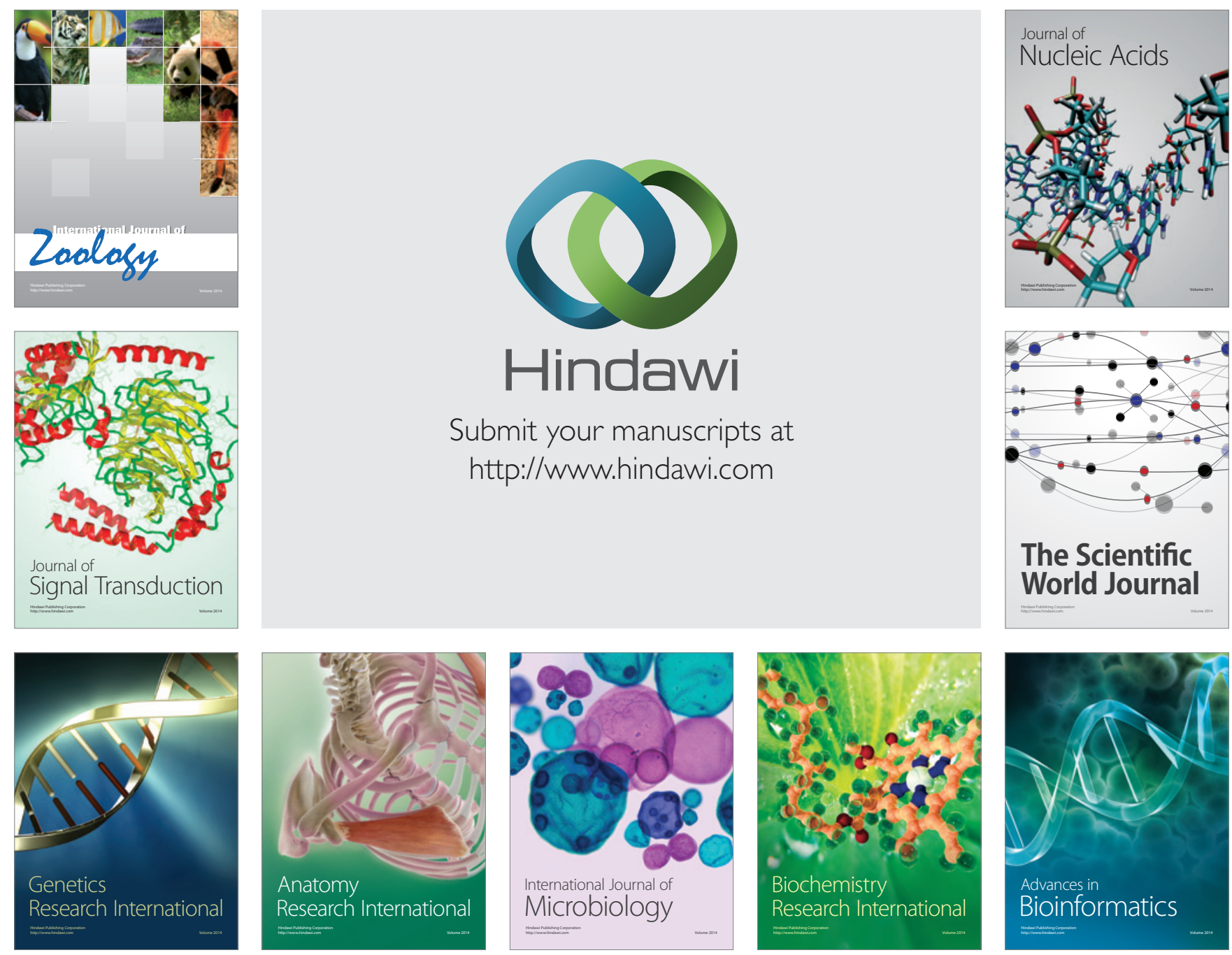

The Scientific World Journal
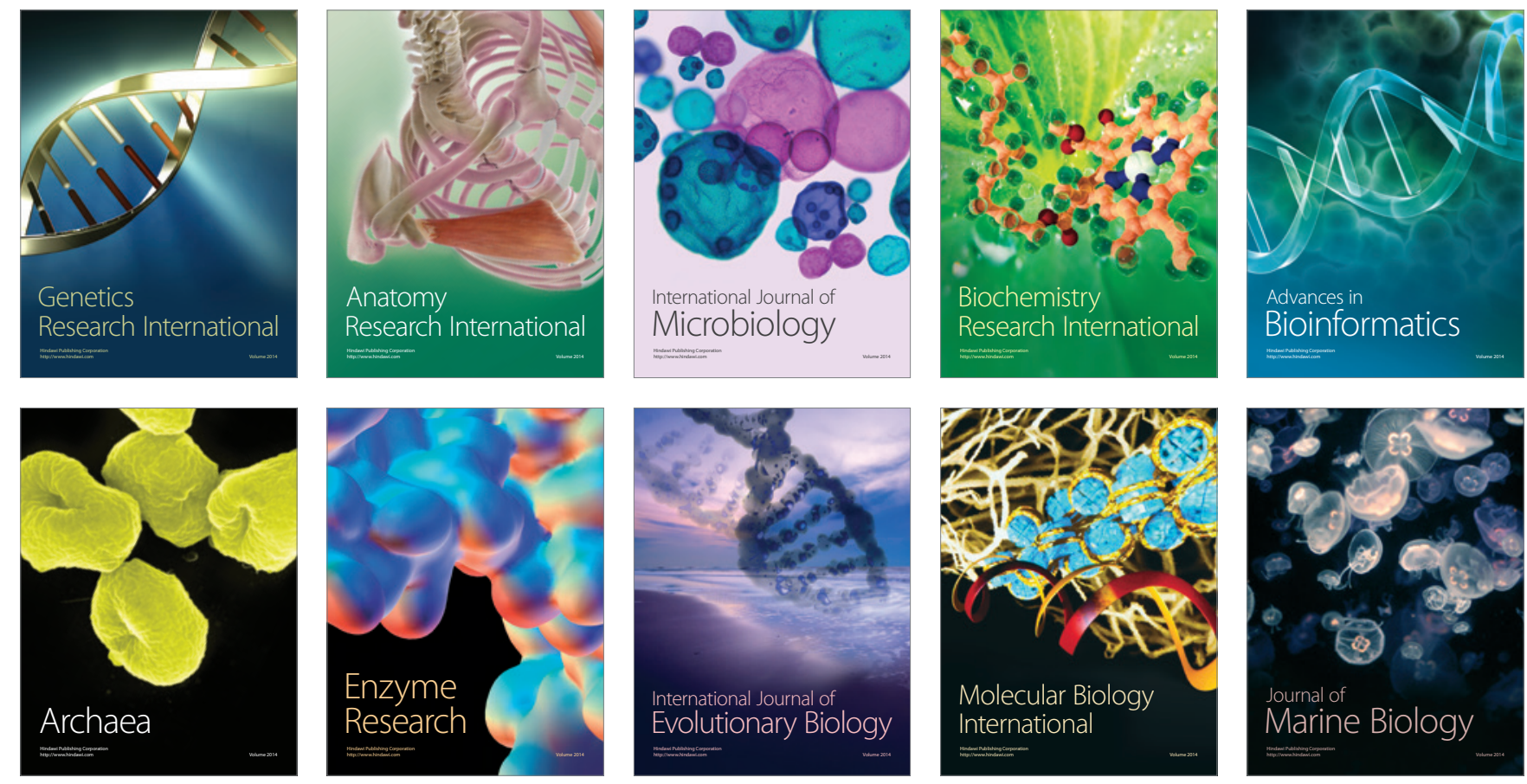